\title{
Serological, Molecular, and Pathotype Diversity of Pepper veinal mottle virus and Chili veinal mottle virus
}

\author{
Benoît Moury, Alain Palloix, Carole Caranta, Patrick Gognalons, \\ Sylvie Souche, Kahsay Gebre Selassie, and Georges Marchoux
}

First, fourth, fifth, sixth, and seventh authors: Station de Pathologie Végétale, Institut National de la Recherche Agronomique, F-84143 Montfavet cedex, France; and second and third authors: Unité de Génétique et d'Amélioration des Fruits et Légumes, Institut National de la Recherche Agronomique, F-84143 Montfavet cedex, France.

Accepted for publication 26 October 2004.

\begin{abstract}
Moury, B., Palloix, A., Caranta, C., Gognalons, P., Souche, S., Gebre Selassie, K., and Marchoux, G. 2005. Serological, molecular, and pathotype diversity of Pepper veinal mottle virus and Chili veinal mottle virus. Phytopathology 95:227-232.

Variability within the pepper-infecting potyviruses Pepper veinal mottle virus (PVMV) and Chili veinal mottle virus (ChiVMV) in Africa and Asia was investigated. Coat protein (CP) gene sequence diversity revealed three clades that corresponded to three geographic locations and there was no evidence of presence of the ChiVMV/Asian group in western or central Africa. These clades included closely related isolates that potentially belong to two viral species, which is consistent with current nomenclature. These clades could not be unambiguously identified with poly-
\end{abstract}

ABSTRACT clonal antisera; however, reverse transcription-polymerase chain reactions allowed differentiation of the isolates into two species based on a large indel in the CP gene. PVMV and ChiVMV isolates were classified into three and two pathotypes, respectively, in relation to pepper genotypes carrying different resistance factors. Specificity of resistance only partially corresponded to molecular diversity of the isolates. Only one isolate of PVMV could infect pepper genotypes carrying the two recessive genes pvr6 and $p v r 2^{2}$; however, these genotypes were not infected by PVMV in field trials in Senegal, despite a high prevalence of PVMV in the surrounding pepper plants.

Additional keyword: etiology.

cultivars remain the most economical and reliable method of control. In pepper, few sources of resistance to PVMV have been characterized. Combination of the pvr6 gene, originating from the Indian cv. Perennial, and of the $p v r 2^{l}$ or $p v r 2^{2}$ alleles confers high level resistance to PVMV (7; data not shown), whereas neither $p v r 6, p v r 2^{l}$, or $p v r 2^{2}$ alone confer any resistance to this virus. Perennial also is resistant to potyvirus E (a virus related to PVMV isolated from pepper in Ethiopia in 1977; K. Gebre Selassie, unpublished data) and this resistance involves six additive or epistatic quantitative trait loci (QTLs) (6).

A network program, including breeders and geneticists from Africa, Asia, and West Indies, was initiated to create pepper cultivars resistant to the most damaging diseases (29). To facilitate breeding of pepper cultivars with wide-spectrum Potyvirus sp. resistance and deployment on a regional scale, we provide here an evaluation of the serological, molecular, and pathotype diversity of PVMV and ChiVMV in relation to sources of resistance.

\section{MATERIALS AND METHODS}

Virus isolates. Isolates related to PVMV, ChiVMV, or both (Table 1) were used to develop serological and molecular diagnostic methods and to study host range in solanaceous hosts. PVY isolate To-72 (13) also was used for serological tests and represented a more distantly related Potyvirus sp. In addition, two surveys of pepper production fields or experimental trials were conducted in Senegal in May 2001 (in the Dakar, Thiès, and Saint Louis du Sénégal areas) and May 2002 (in the Dakar and Mboro areas). In the Dakar area, 60 different pepper genotypes, including 15 breeding lines homozygous for both the $p v r 2^{2}$ and $p v r 6$ alleles, were grown and surveyed for virus infection. Leaf and fruit samples were collected from plants showing symptoms of possible viral etiology and further tested by enzyme-linked immunosorbent 
assay (ELISA) for infection by PVMV, ChiVMV, PVY, Tomato spotted wilt virus (TSWV), Tobacco mosaic virus (TMV), Pepper mild mottle virus (PMMoV), and Cucumber mosaic virus (CMV).

Serological tests. Several polyclonal antisera were produced in our laboratory or were gifts from other researchers (26) (Table 2). Double-antibody sandwich (DAS)-ELISAs were performed on samples from infected pepper plants (cv. Yolo Wonder) as described previously (24). Samples were considered positive when absorbance values were at least three times greater than the mean absorbance value of five healthy control samples.

Sequence analyses. Three degenerate oligonucleotide primers (Table 3, A, B, and C) were defined in regions of the NIb and coat protein $(\mathrm{CP})$ genes where conservation was observed at the amino acid level among PVY, PepMoV, TEV, and ChiVMV. RNA was extracted from infected plant material (Tri Reagent kit; Molecular Research Center Inc., Cincinnati, $\mathrm{OH}$ ) and a reverse transcription (RT) step was performed with the polyT primer (Table 3) and
Avian myeloblastosis virus reverse transcriptase (Promega Corp., Madison, WI). Two overlapping cDNA fragments covering the 3'proximal terminus of the NIb gene, the entire $\mathrm{CP}$ gene, and the $3^{\prime}$ nontranslated region (NTR) of PVMV were further amplified by polymerase chain reaction (PCR) using Taq DNA polymerase (Promega Corp.) and primers $\mathrm{A}$ and $\mathrm{B}$ or primers $\mathrm{C}$ and polyT. These RT-PCR fragments were purified, treated with the Klenow fragment of DNA polymerase I, and cloned into the SmaI site of pUC13. For each cDNA fragment, nucleotide sequence reactions of two clones were performed by Genome Express (Meylan, France). The sequence of the CP gene of PVMV isolates CAC2, F-Bot, S31, potyvirus E, and Y90/34 were deposited in GenBank under accession nos. AJ780966 to AJ780970. CP sequences from potyviruses infecting solanaceous crops (Table 1) were aligned using the ClustalW program, version 1.8 (37). These alignments were used to define PCR primers D and E (Table 3) for specific detection and differentiation of PVMV and ChiVMV. Phyloge-

TABLE 1. Potyvirus isolates compared

\begin{tabular}{|c|c|c|c|c|}
\hline Virus $^{\mathrm{a}}$ & Isolate & Country & Collected by donor or reference & GenBank accession no. \\
\hline PVMV & $\mathrm{CAC} 2$ & Senegal & A. Palloix & AJ780966 \\
\hline PVMV & CAC3 & Senegal & H. Laterrot & $\ldots$ \\
\hline PVMV & $\mathrm{CAC} 4$ & Senegal & H. Laterrot & $\ldots$ \\
\hline PVMV & CAC94 & Senegal & H. Laterrot & $\ldots$ \\
\hline PVMV & F-Bot & Cameroon & R. Nono Womdim & AJ780967 \\
\hline PVMV & $\mathrm{S} 23$ & Ghana & A. A. Brunt & $\ldots$ \\
\hline PVMV & $\mathrm{S} 31$ & Ghana & A. A. Brunt & AJ780968 \\
\hline PVMV & Y90/34 & Yemen & D. Walkey & AJ780969 \\
\hline PVMV & Potyvirus E & Ethiopia & K. Gebre Selassie & AJ780970 \\
\hline PVMV & $\mathrm{IC}$ & Ivory Coast & J. J. De Wijs; 15 & $\ldots$ \\
\hline PVMV & TU2 & Tunisia & 15 & $\ldots$ \\
\hline ChivMV & Taiwan & China (Taiwan) & S. K. Green & $\ldots$ \\
\hline ChiVMV & Beijing & China & B. Moury & $\ldots$ \\
\hline ChiVMV & India & India & 20 & $\mathrm{AJ} 237843$ \\
\hline ChiVMV & Japan & Japan & $\ldots$ & AB012221 \\
\hline ChiVMV & Thai & Thailand & 8 & U72193 \\
\hline PVY & To-72 & France & 13 & $\ldots$ \\
\hline PVY & SON41 & France & 24 & AJ439544 \\
\hline PVY & $\mathrm{N}$ & France & 32 & D00441 \\
\hline PVY & $\mathrm{O}$ & Canada & 33 & U09509 \\
\hline PepSMV & $\ldots$ & Argentina & 31 & X66027 \\
\hline PepYMV & $\ldots$ & Brazil & 19 & AF348610 \\
\hline PepMoV & $\mathrm{C}$ & United States (California) & 38 & M96425 \\
\hline PepMoV & FL & United States (Florida) & 41 & AF501591 \\
\hline PTV & PPK13 & Peru & 35 & AJ437280 \\
\hline PVV & M97 & United Kingdom & 28 & $\mathrm{AJ} 253123$ \\
\hline PVV & PA10 & Peru & 35 & AJ516021 \\
\hline WPMV & $\ldots$ & Peru & 36 & AJ437279 \\
\hline TVMV & $\ldots$ & $\ldots$ & 11 & X04083 \\
\hline PVA & HER & Finland & 21 & AJ131400 \\
\hline PVA & $\mathrm{U}$ & United States & 21 & AJ131402 \\
\hline TEV & HAT & $\ldots$ & 2 & M11458 \\
\hline TEV & NW & United States (Louisiana) & 9 & L38714 \\
\hline
\end{tabular}

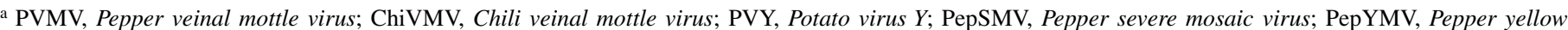
mosaic virus; PTV, Peru tomato virus; PVV, Potato virus V; WPMV, Wild potato mosaic virus; TVMV, Tobacco vein-mottling virus; PVA, Potato virus A; TEV, Tobacco etch virus.

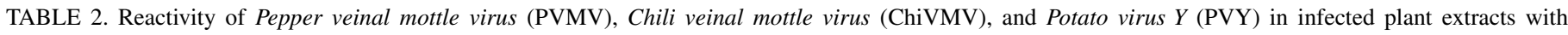
polyclonal antibodies by double-antibody sandwich enzyme-linked immunosorbent assay (DAS-ELISA)

\begin{tabular}{|c|c|c|c|c|c|c|}
\hline \multirow[b]{2}{*}{ Virus species/isolate } & \multicolumn{6}{|c|}{ Sources of polyclonal antibodies ${ }^{\mathrm{a}}$} \\
\hline & $\begin{array}{l}\text { F-Bot } \\
\text { INRA }\end{array}$ & $\begin{array}{l}\text { PVMV 374/94 } \\
\text { H. J. Vetten }\end{array}$ & $\begin{array}{c}\text { Y90/34 } \\
\text { D. G. A. Walkey }\end{array}$ & $\begin{array}{l}\text { Potyvirus E } \\
\text { INRA }\end{array}$ & $\begin{array}{l}\text { ChiVMV } \\
\text { Japan }\end{array}$ & $\begin{array}{l}\text { PVY To-72 } \\
\text { INRA }\end{array}$ \\
\hline PVMV/CAC2, CAC3, CAC4, CAC94, F-Bot, IC, S23, S31 & ++ & + & ++ & + & + & 0 \\
\hline PVMV/Y90-34 & + & + & ++ & ++ & ++ & 0 \\
\hline PVMV/potyvirus E & + & ++ & ++ & ++ & ++ & 0 \\
\hline ChiVMV/Taiwan, Beijing, Thai & 0 & 0 & + & + & ++ & 0 \\
\hline PVY/To-72 & + & + & 0 & + & 0 & ++ \\
\hline
\end{tabular}

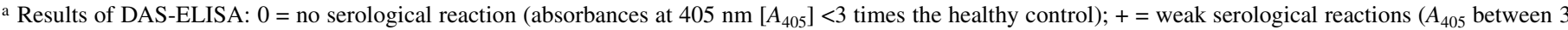
and 5 times the healthy control); $++=$ strong serological reactions $\left(A_{405}>20\right.$ times the healthy control). There were no reactions between 6 and 19 times the healthy control. 
netic construction and evaluation was done using neighbor-joining, Fitch and Margoliash, and maximum likelihood methods implemented in the PHYLIP software package, version 3.5c (12). In all, 1,000 bootstrap replications were performed to place confidence estimates on groups in the most parsimonious unrooted trees. All branches with $<70 \%$ bootstrap support were considered inconclusive and collapsed (16).

Plant materials and resistance tests. Infectivity of PVMV and ChiVMV isolates was assessed by mechanical inoculation onto tomato cv. Momor, N. benthamiana Domin., N. glutinosa L., tobacco cv. Xanthi-nc, $S$. melongena cv. Violette de Barbentane, Petunia $\times$ hybrida cv. Rose du ciel, D. stramonium, and five pepper lines with various resistance genes to potyviruses. Apical leaves of $N$. benthamiana or $N$. glutinosa plants showing symptoms were ground $\left(1 \mathrm{~g} \mathrm{ml}^{-1}\right)$ in $0.03 \mathrm{M} \mathrm{Na}_{2} \mathrm{HPO}_{4}$ buffer (pH 7.0) plus $0.2 \%$ (wt/vol) sodium diethyldithiocarbamate, Carborundum, and activated charcoal (75 mg ml $\mathrm{m}^{-1}$ each) and used for inoculation. The oldest two leaves of 4-week-old plants were inoculated manually. We performed two independent experiments with 20 and 30 plants per pepper genotype-virus isolate combination. Experiments were conducted in insect-proof greenhouses where temperature varied between 18 and $25^{\circ} \mathrm{C}$ (autumn) and 20 and $27^{\circ} \mathrm{C}$ (spring). Symptoms were recorded regularly for 6 weeks postinoculation and DAS-ELISA tests were performed on apical, noninoculated leaves at 15,30 , and 45 days after inoculation.

\section{RESULTS AND DISCUSSION}

Serological and molecular relationships of PVMV and ChiVMV isolates. DAS-ELISAs were performed on $10 \mathrm{PVMV}$ isolates, 3 ChiVMV isolates, and PVY isolate To-72 using different polyclonal antibodies (Table 2). Reactions to homologous antibodies were always strong ( $>20$ times the mean healthy control). Antibodies raised against isolates Y90/34, potyvirus E, and ChiVMV reacted to all PVMV and ChiVMV isolates with varying intensities. The 10 PVMV isolates were detected by the five antibodies raised against isolates F-Bot, 374/94, Y90/34, potyvirus E, and a Japanese isolate of ChiVMV. Such broad-spectrum detection indicated either cross reactivity due to a relatively high level of similarity, or that most of these isolates were mixtures of more distantly related viral entities. Polyclonal antibodies raised against isolate To-72 of PVY did not detect any of the PVMV or ChiVMV isolates; however, isolate To-72 was weakly detected by the antibodies raised against F-Bot, 374/94, and potyvirus E.
To assess more precisely the diversity within PVMV and the relationships with ChiVMV and other Potyvirus spp., the nucleotide sequence of the 3'-proximal part of the NIb gene, the entire $\mathrm{CP}$ gene, and the $3^{\prime}$ NTR of PVMV isolates F-Bot, S31, CAC2, Y90/34, and potyvirus E were determined. For each cDNA fragment, the nucleotide sequences from two clones were identical. These sequences first were compared with PVMV isolates IC (Ivory Coast) and TU2 (Tunisia) (15). Multiple alignments of the $\mathrm{CP}$ sequences did not have gaps. Percentages of nucleotide identity varied from 81.4 to 97.2 . Isolates from western or central Africa were more closely related to each other (nucleotide identity $>90 \%$ ) than to the Ethiopian (potyvirus E) or the Yemeni (Y90/34) isolates (nucleotide identity between 81.4 and $86.0 \%$ ). The CP sequences of PVMV also were compared with three CP sequences of ChiVMV available in databanks and with other potyviruses infecting solanaceous crops (Table 1). Alignment of the 5'-proximal sequences of the $\mathrm{CP}$ gene were not reliable. In all, 51 additional nucleotides corresponding to 17 codons were present in this region in the three ChiVMV sequences compared with the PVMV sequences. The 708 nucleotides at the $3^{\prime}$ end of the CP gene aligned without gaps and were used to calculate percent identity between ChiVMV, PVMV, and other potyviruses (Table 4). Pairwise identity between ChiVMV and PVMV isolates (from 77.7 to $82.2 \%$ ) were less than within PVMV isolates (from 85.9 to $96.8 \%$ ). Other potyviruses infecting solanaceous crops shared $<70 \%$ nucleotide identity with PVMV or ChiVMV (Table 4). The same groups were determined based on the whole CP gene and considering a single 51-nucleotide indel in the 5'-proximal region of the alignment; however, percent identities were lower (e.g., 74.0 to $77.3 \%$ between ChiVMV and PVMV). Based on the threshold of $85 \%$ nucleotide sequence identity in the genome of potyviruses that was proposed to differentiate species (39), all PVMV isolates from western or central Africa belong to the same species as isolates Y90/34 and potyvirus E but are distinct from ChiVMV. This result validates the current taxonomic status of PVMV and ChiVMV as two distinct species, and places isolates Y90/34 and potyvirus E unambiguously as PVMV. In addition, the relatively high amino acid identity within the PVMV/ ChiVMV group explains the serological cross reactivity observed between PVMV isolates and antibodies raised against a ChiVMV isolate (Table 2).

A phylogenetic tree was built from the alignment of the $708 \mathrm{nu}-$ cleotides at the $3^{\prime}$ end of the $\mathrm{CP}$-coding region. Whatever the reconstruction method (described previously), a unique consensus

TABLE 3. Primers used to sequence the coat protein (CP) gene of Pepper veinal mottle virus (PVMV) and for detection and differentiation of PVMV and Chili veinal mottle virus

\begin{tabular}{llc}
\hline Primer name & \multicolumn{1}{c}{ Primer sequence $\left(5^{\prime}-3^{\prime}\right)^{\mathrm{a}}$} & Genomic location $^{\mathrm{b}}$ \\
\hline $\mathrm{A}$ & GIACITT(T/C)ACIGC(G/A/T/C)GC(G/A/T/C)CC & $7,570-7,588(\mathrm{NIb}$ gene) \\
$\mathrm{B}$ & TC(G/A/T/C)A(T/C)CAT(G/A/T/C)ACCCACAT(G/A/T/C)CC & $8,955-8,974(\mathrm{CP}$ gene) \\
C & ATGGTITGGTG(T/C)AT(A/T/C)GA(G/A)AA(T/C)GG & $8,913-8,935$ (CP gene) \\
polyT & GGATCCTTTTTTTTTTTTTTTTTT(A/C/G) & $3^{\prime}$ Nontranslated region \\
D & GGIAA(A/G)GC(G/A/T/C)CC(G/A/T/C)TA(C/T)AT & $8,421-8,438($ NIb gene) \\
E & CGCGCTAATGACATATCGGT & $9,138-9,157$ (CP gene) \\
\hline
\end{tabular}

${ }^{\mathrm{a}} \mathrm{I}=$ inosine.

b Numbers are according to Potato virus $Y$ isolate SON41 (accession no. AJ439544).

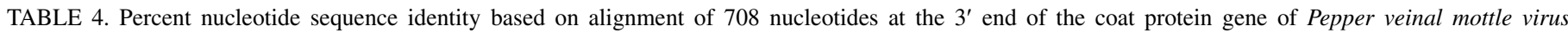
(PVMV), Chili veinal mottle virus (ChiVMV), and other potyviruses infecting solanaceous crops ${ }^{\mathrm{a}}$

\begin{tabular}{|c|c|c|c|}
\hline & ChiVMV & IC, TU2, F-Bot, S31, CAC2 & Potyvirus E, Y90/34 \\
\hline ChivMV & 90.3 to 92.8 & & $\ldots$ \\
\hline IC, TU2, F-Bot, S31, CAC2 & 77.7 to 80.6 & 91.2 to 96.8 & $\ldots$ \\
\hline Potyvirus E, Y90/34 & 77.8 to 82.2 & 85.9 to 88.3 & 89.0 \\
\hline Others ${ }^{b}$ & $<70.0$ & $<70.0$ & $<70.0$ \\
\hline
\end{tabular}

a Ranges obtained for pairwise comparisons.

b Viruses and accession numbers mentioned in Table 1 . 


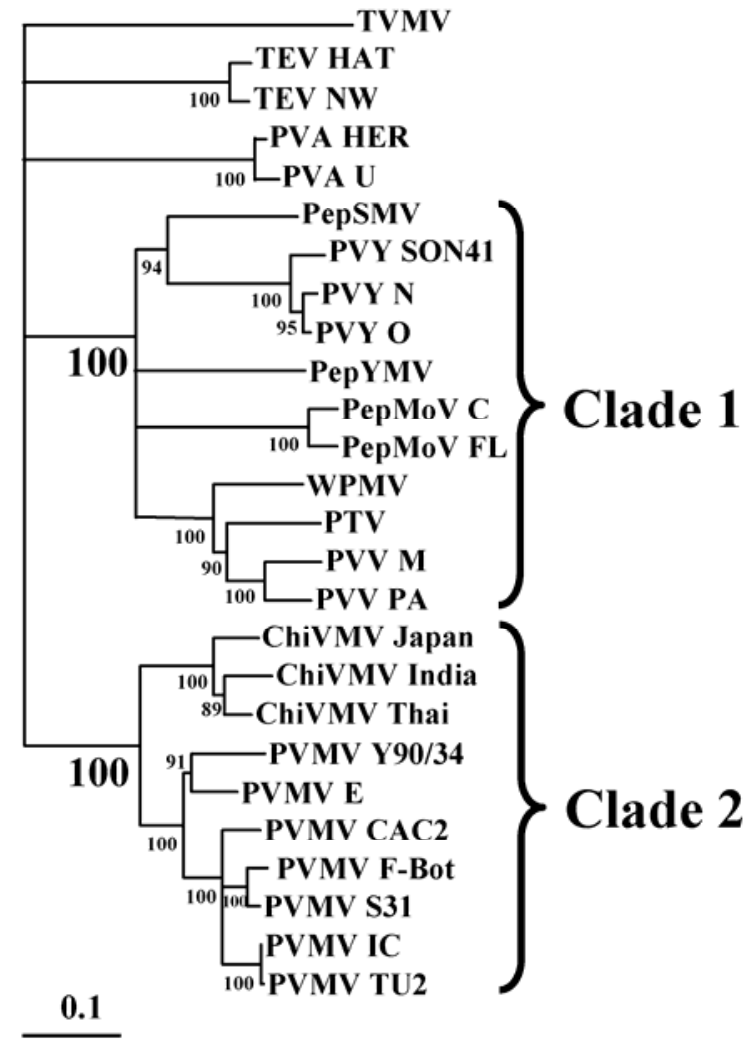

Fig. 1. Unrooted neighbor-joining phylogenetic tree representing an alignment of 708 nucleotides at the $3^{\prime}$ end of the coat protein gene of potyviruses infecting solanaceous crops. Bootstrap analysis was applied using 1,000 bootstrap samples. Bootstrap values $>70 \%$ at internal nodes are reported. The scale bar represents the relative genetic distance.

tree topology was obtained (Fig. 1). Bootstrap values associated to the branches of the tree supported the existence of two major clades (Fig. 1). The first clade includes PVY, PepMoV, Pepper yellow mosaic virus, Pepper severe mosaic virus, Peru tomato virus, Potato virus $V$, and Wild potato mosaic virus, as mentioned by Spetz et al. (35). The second one includes PVMV and ChiVMV. Viruses within the first clade do not share common geographic distributions or plant host ranges. Thus, the evolutionary forces that drove speciation within this group are as yet unknown and may be complex. The PVMV/ChiVMV clade comprises three subgroups: the east Asian ChiVMV isolates, the Ethiopian and Yemeni PVMV isolates, and the west and central African PVMV isolates, which correspond to the groups obtained with pairwise similarities (Fig. 1; Table 4). It is possible that geographic isolation was responsible for diversification within this group.

Specific detection of PVMV and ChiVMV by RT-PCR. Based on the sequences of the NIb and CP genes available for PVMV, ChiVMV, PVY, PepMoV, and TEV, we defined primers D and E (Table 3) to specifically detect viruses of the PVMV/ ChiVMV group and to distinguish PVMV from ChiVMV. Primer $\mathrm{D}$ is a degenerate primer that corresponds to the 'GKAPYI' amino acid motif common to the NIb protein of PVMV, ChiVMV, PVY, and PepMoV but which is slightly different from the 'GKAPYL' motif in TEV. Primer E corresponds to the 'TDMSLAR' amino acid motif conserved in the CP of PVMV, ChiVMV, and TEV but not in PVY and PepMoV. Therefore, RT-PCR experiments conducted with primers D and E are expected to give a 737-bp DNA fragment with PVMV isolates, a 788-bp DNA fragment with ChiVMV, and no DNA amplification with PVY or PepMoV. Based on sequences available in GenBank, TEV is expected to differ at one or two nucleotide positions in the $3^{\prime}$ end of primer D. Consequently, RT-PCR on TEV RNA with primers D and E could

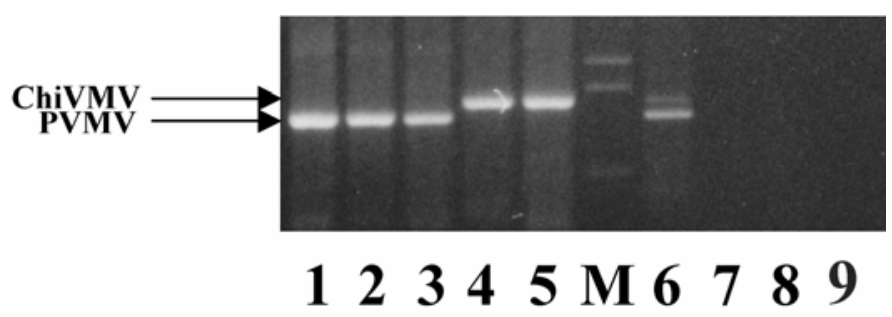

Fig. 2. Reverse transcription-polymerase chain reaction products obtained with primers D and E (Table 3) using RNA extracts from pepper plants infected with individual potyviruses or potyvirus combinations. Lanes 1 to 3 , Pepper veinal mottle virus (PVMV) isolates; lanes 4 and 5, Chili veinal mottle virus (ChiVMV) isolates; lane 6, size marker; lane 7, PVMV and ChiVMV mixed infection; lane 8, healthy control; and lane 9, Potato virus $Y$.

give a 737-bp DNA fragment or no amplification at all, depending on the sequence and PCR conditions. RT-PCR experiments conducted on RNA extracts from PVMV isolates F-Bot, S31, CAC2, Y90/34, and potyvirus E gave a DNA product of the expected size. The specificity of primers D and $\mathrm{E}$ was evaluated further with PVMV isolates CAC3, CAC4, CAC94, CAF1, and S23; with ChiVMV isolates Taiwan, Beijing, and Thai; and with a limited number of reference isolates of PVY, TEV, and PepMoV (Table 1). Only isolates from the PVMV/ChiVMV group amplified a DNA product. The ChiVMV and PVMV isolates produced DNA fragments of expected size (Fig. 2). RT-PCR experiments conducted with primers D and E on RNA extracted from a Yolo Wonder pepper plant infected with both isolates F-Bot of PVMV and Taiwan of ChiVMV produced the same two fragments obtained separately from each isolate (Fig. 2). Consequently, these primers could be used to reveal mixed infections. Moreover, the single-fragment profiles obtained by RT-PCR from the PVMV and ChiVMV isolates under study indicated that these isolates are not mixtures of PVMV and ChiVMV.

Host range of PVMV. In all, 10 PVMV and 3 ChiVMV isolates revealed few differences in host range among several solanaceous species (data not shown). All 13 isolates induced systemic mosaic symptoms in $N$. benthamiana, $N$. glutinosa, and Petunia $\times$ hybrida whereas none infected $S$. melongena. Y90/34 was the only isolate able to systemically infect $D$. stramonium. Symptomless infections were observed in N. tabacum with the four PVMV isolates from Senegal (CAC2, CAC3, CAC4, and CAC94) and the three ChiVMV isolates. Symptomless infection of tomato with PVMV isolates CAC2, CAC4, S23, S31, and IC also was observed.

Five pepper genotypes known to possess resistance factors against potyviruses were evaluated (Table 5). Yolo Wonder and Florida VR2 were infected by all isolates tested and exhibited systemic mosaic symptoms. CM334 was susceptible to all isolates of PVMV and ChiVMV but exhibited a delay in onset and reduced intensity of systemic symptoms after inoculation with PVMV isolates Y90/34 and potyvirus $\mathrm{E}$ and ChiVMV isolate Taiwan. CM334 carries the two Potyvirus sp. resistance genes Pvr4 and pvr5. Pvr4 confers a high level of resistance to PVY and PepMoV isolates, with no virus detection in the inoculated or apical leaves, whereas pvr5 confers a phenotypically similar resistance to PVY pathotype 0 (10). The partial resistance of CM334 to potyvirus E was found to be linked to pvr5 (A. Palloix, unpublished data). However, we do not know if the same gene or genes also confer partial resistance to PVMV isolate Y90/34 and to ChiVMV isolate Taiwan. We also do not know if the same gene in the $p v r 5$ region confers the high-level resistance to PVY 0 and the partial resistance to potyvirus $\mathrm{E}$.

The DH801 line possessing the $p v r 2^{2}$ and pvr6 genes gave the broadest resistance and did not support systemic infection by PVMV or ChiVMV (Table 5). This was confirmed during multiple inoculation tests performed in the breeding program for resis- 
TABLE 5. Pathogenicity of Pepper veinal mottle virus (PVMV) and Chili veinal mottle virus (ChiVMV) isolates on pepper genotypes carrying various resistance systems $^{\mathrm{a}}$

\begin{tabular}{|c|c|c|c|c|c|}
\hline \multirow[b]{2}{*}{ C. аппиит genotype } & \multirow[b]{2}{*}{ Potyvirus resistance genes ${ }^{b}$} & \multicolumn{2}{|l|}{ PVMV isolates } & \multicolumn{2}{|c|}{ ChiVMV isolates } \\
\hline & & CAC2, CAC3, CAC4, CAC94, IC, F-Bot, S23, S31 & Y90/34, potyvirus E & Beijing, Thai & Taiwan \\
\hline Yolo Wonder & $\ldots$ & S & S & S & $S$ \\
\hline Florida VR2 & $p v r 2^{2}$ & $\mathrm{~S}$ & $\mathrm{~S}$ & $\mathrm{~S}$ & $\mathrm{~S}$ \\
\hline CM334 & Pvr4, pvr5 & $\mathrm{S}$ & $\mathrm{r}$ & $\mathrm{S}$ & $\mathrm{r}$ \\
\hline Perennial & Several QTLs, pvr6 & $\mathrm{S}$ & $\mathrm{R}^{\mathrm{c}}$ & $\mathrm{R}$ & $\mathrm{R}$ \\
\hline DH801 ${ }^{\mathrm{d}}$ & $p v r 2^{2}, p v r 6$ & $\mathrm{R}^{\mathrm{e}}$ & $\mathrm{R}$ & $\mathrm{R}$ & $\mathrm{R}$ \\
\hline
\end{tabular}

${ }^{a} \mathrm{~S}=$ accumulation of virus and symptom expression at the systemic level; $r=$ accumulation of virus but few symptoms at the systemic level; $\mathrm{R}=$ no virus accumulation at the systemic level.

b According to Kyle and Palloix (22)

${ }^{c}$ Polygenic resistance to potyvirus E (6).

d Doubled-haploid lines derived from the $\mathrm{F}_{1}$ hybrid between Florida VR2 and Perennial.

${ }^{\mathrm{e}}$ Digenic resistance due to a complementation between $p v r 2^{2}$ and $p v r 6$ characterized against S23, F-Bot, and IC (7).

tance to potyviruses (10 tests performed between 1994 and 2004). However, during the introgression of the digenic resistance from DH801 into bell pepper lines, 1 of 120 plants displayed delayed symptoms on fruit following inoculation with the IC isolate of PVMV. Back-inoculations of DH801 plants with virus extracted from this fruit showed 100\% (45 of 45 inoculated plants) systemic infection. This adapted PVMV isolate showed the same host range and symptom expression as isolate IC, except for DH801 plants.

'Perennial' showed resistance to East African and Asian PVMV or ChiVMV isolates but not to West African PVMV isolates. The phenotype of the resistance was similar to that of DH801. Consequently, Perennial could be used to breed pepper cultivars resistant to PVMV and ChiVMV in Asia. However, more isolates in these groups should be evaluated for pathogenicity on Perennial. Characterization of as few as three ChiVMV isolates with five pepper genotypes revealed pathogenicity differences (Table 5), suggesting that much variability exists within ChiVMV. The resistance of Perennial to potyvirus $\mathrm{E}$ was shown to be conferred by four additive and two epistatic QTLs (6). It remains to be determined if the same QTLs (or some of them) are effective against PVMV isolate Y90/34 and especially against ChiVMV isolates, which are more distant. Perennial is the only known pepper genotype with broad resistance corresponding to the geographic distribution and phylogenetic grouping of PVMV and ChiVMV isolates. In spite of the relatively small number of isolates tested, an explanation could be that acquisition or loss of pathogenicity toward Perennial was more ancestral than acquisition or loss of pathogenicity toward CM334 or DH801.

Incidence of PVMV in pepper in Senegal. During surveys in 2001 and 2002, severe mosaic symptoms in pepper were observed on more than $50 \%$ of the plants. More rarely, necrosis on leaves and an irregular ripening of bell pepper fruit were observed. In 2001 and 2002, 14 of 28 and 25 of 26 samples, respectively, from plants showing virus symptoms reacted positively for at least one virus in DAS-ELISA. Detection of the viruses was efficient in both leaves and fruit. Each year, positive serological reactions to PVMV or ChiVMV were more frequent than any other tested virus and recorded for all locations sampled. CMV also was detected in 2001 (three samples) and PMMoV was detected in 2002 (one sample). RT-PCR experiments with primers D and E were conducted on 17 isolates that reacted positively both to PVMV and ChiVMV in DAS-ELISA. Only DNA fragments with the specific size corresponding to PVMV were obtained. This suggested that ChiVMV was not present in the collected samples and confirmed that serological cross reactions occurred between ChiVMV and PVMV.

The DH801 pepper genotype and 15 breeding lines homozygous for both the $p v r 2^{2}$ and $p v r 6$ alleles tested negative for PVMV and ChiVMV in DAS-ELISA despite a high prevalence of the virus in the surrounding plants in the trials. Therefore, either appearance of virulent isolates is a rare event or virulent isolates are less fit and do not spread efficiently in the agroecosystem. However, it should be emphasized that no pepper cultivars with resistance to PVMV presently are grown on a large scale in the region. If PVMV variants able to overcome the resistance conferred by DH801 can be generated, their frequency may be expected to increase rapidly if cultivars with resistance derived from DH801 are deployed.

\section{ACKNOWLEDGMENTS}

We thank C. Duranton and R. N. Womdim (Technisem-Tropicasem, Senegal) and Z. Baoxi and W. Lihao (IVF-CAAS, China) for assistance in collecting virus samples, and D. Fargette for reading the manuscript before its submission.

\section{LITERATURE CITED}

1. Alegbejo, M. D. 1999. Physalis micrantha L., a weed host of pepper veinal mottle virus. J. Veg. Crop Prod. 5:59-66.

2. Allison, R. F., Dougherty, W. G., Parks, T. D., Willis, L., Johnston, R. E., Kelly, M., and Armstrong, F. B. 1985. Biochemical analysis of the capsid protein gene and capsid protein of tobacco etch virus: $\mathrm{N}$-terminal amino acids are located on the virion's surface. Virology 147:309-316.

3. Atiri, G. I. 1986. A disease of fluted pumpkin (Telfaira occidentalis Hook. F.) caused by a yellow vein-clearing strain of pepper veinal mottle virus in Nigeria. J. Plant Prot. Tropics 3:105-110.

4. Bidari, V. B., and Reddy, H. R. 1983. Prevalence of chili viruses in Dharwad district. Plant Pathol. Newsl. 1:11-12.

5. Brunt, A. A., Kenten, R. H., and Phillips, S. 1978. Symptomatologically distinct strains of pepper veinal mottle virus from four West Africa solanaceous crops. Ann. Appl. Biol. 88:115-119.

6. Caranta, C., Lefebvre, V., and Palloix, A. 1997. Mapping polygenic resistance to potyviruses in pepper: Identification of specific and new broad spectrum resistance factors with quantitative effects. Mol. PlantMicrobe Interact. 10:872-878.

7. Caranta, C., Palloix, A., Gebre Selassie, K., Lefebvre, V., Moury, B., and Daubèze, A.-M. 1996. A complementation of two genes originating from susceptible Capsicum annuum lines confers a new and complete resistance to Pepper veinal mottle virus. Phytopathology 86: 739-743.

8. Chiemsombat, P., Sae-Ung, N., Attathom, S., Patarapuwadol, S., and Siriwong, P. 1998. Molecular taxonomy of a new potyvirus isolated from chili pepper in Thailand. Arch. Virol. 143:1855-1863.

9. Chu, M. H., Johnson, M., Thornbury, D. W., Black, L., and Pirone, T. P. 1995. Nucleotide sequence of a strain of tobacco etch virus that does not cause Tabasco pepper wilt. Virus Genes 10:283-288.

10. Dogimont, C., Palloix, A., Daubèze, A.-M., Marchoux, G., Gebre Selassie, K., and Pochard, E. 1996. Genetic analysis of broad spectrum resistance to potyviruses using doubled haploid lines of pepper (Capsicum aпnиum L.). Euphytica 88:231-239.

11. Domier, L. L., Franklin, K. M., Shahabuddin, M., Hellmann, G. M., Overmeyer, J. H., Hiremath, S. T., Siaw, M. F., Lomonossoff, G. P., Shaw, J. G., and Rhoads, R. E. 1986. The nucleotide sequence of tobacco vein mottling virus RNA. Nucleic Acids. Res. 14:5417-5430.

12. Felsenstein, J. 1989. PHYLIP: Phylogeny Inference Package (version 3.2) Cladistics 5:164-166. 
13. Gebre Selassie, K., Marchoux, G., Delecolle, B., and Pochard, E. 1985. Variabilité naturelle des souches du virus Y de la pomme de terre dans les cultures de piment du sud-est de la France. Caractérisation et classification en pathotypes. Agronomie 5:621-630.

14. Givord, L. 1982. Pepper veinal mottle virus in the weed Physalis angulata in the Ivory Coast. Plant Dis. 66:1081-1082.

15. Gorsane, F., Fakhfakh, H., Tourneur, C., Marrakchi, M., and Makni, M. 2001. Nucleotide sequence comparison of the $3^{\prime}$ terminal region of the genome of pepper vein mottle virus isolates from Tunisia and Ivory Coast. Arch. Virol. 146:611-618.

16. Hillis, D. M., and Bull, J. J. 1993. An empirical test of bootstrapping as a method for assessing confidence in phylogenetic analysis. Syst. Biol. 42:182-192.

17. Hiskias, Y., Lesemann, D.-E., and Vetten, H. J. 1999. Occurrence, distribution and relative importance of viruses infecting hot pepper and tomato in the major growing areas of Ethiopia. J. Phytopathol. 147:5-11.

18. Huguenot, C., Furneaux, M. T., Clare, J., and Hamilton, R. I. 1996. Serodiagnosis of pepper veinal mottle virus in west Africa using specific monoclonal antibodies in DAS-ELISA. J. Phytopathol. 144:29-32.

19. Inoue-Nagata, A. K., Fonseca, M. E. N., Resende, R. O., Boiteux, L. S., Monte, D. C., Dusi, A. N., de Ávila, A. C., and van der Vlugt, R. A. A. 2002. Pepper yellow mosaic virus, a new potyvirus in sweet pepper, Capsicum annuum. Arch. Virol. 147:849-855.

20. Joseph, J., and Savithri, H. S. 1999. Determination of 3'-terminal nucleotide sequence of pepper vein banding virus RNA and expression of its coat protein in Escherichia coli. Arch. Virol. 144:1679-1687.

21. Kekarainen, T., Merits, A., Oruetxebarria, I., Rajamäki, M. L., and Valkonen, J. P. T. 1999. Comparison $\mathrm{f}$ the complete sequences of five different isolates of Potato virus A (PVA), genus Potyvirus. Arch. Virol. 144:2355-2366.

22. Kyle, M. M., and Palloix, A. 1997. Proposed revision of nomenclature for potyvirus resistance genes in Capsicum. Euphytica 97:183-188.

23. Mills, P. R. 1987. Infection of Capsicum frutescens with potato virus Y and tobacco etch virus in the Sudan. Plant Dis. 71:557.

24. Moury, B., Morel, C., Johansen, E., and Jacquemond, M. 2002. Evidence for diversifying selection in Potato virus $Y$ and in the coat protein of other potyviruses. J. Gen. Virol. 83:2563-2573.

25. Nelson, M. R., Wheeler, R. E., and Zitter, T. A. 1982. Pepper mottle virus. Page 253 in: Descriptions of Plant Viruses. CMI/AAB, Kew, England.

26. Nono Womdim, R., and Alilabentja, N. 1993. Identification and characterization of pepper veinal mottle virus strain in Cameroon. Capsicum Eggplant Newsl. 12:69-72.

27. Nono Womdim, R., Swai, I. S., Chadha, M. L., Gebre Selassie, K., and Marchoux, G. 2001. Occurrence of Chili veinal mottle virus in Solanum aethiopicum in Tanzania. Plant Dis. 85:801.

28. Oruetxebarria, I., Kekarainen, T., Spetz, C., and Valkonen, J. P. T. 2000. Molecular characterization of Potato virus $V$ genomes from Europe indicates limited spaciotemporal strain differentiation. Phytopathology 90:437-444.

29. Palloix, A., Ahmed, E. A., Daubèze, A.-M., Lafortune, D., Depestre, T., Nono Womdim, R., Duranton, C., and Berke, T. 2000. Breeding pepper for durable resistance against worldwide potyviruses: The "LIRA" intertropical network program. Page 56 in: Durable Disease Resistance Symposium, Ede, Wageningen, The Netherlands.

30. Purcifull, D. E., and Hiebert, E. 1982. Tobacco etch virus. Page 258 in: Descriptions of Plant Viruses. CMI/AAB, Kew, England.

31. Rabinowicz, P. D., Bravo-Almonacid, F. F., and Mentaberry, A. N. 1993. cDNA sequence of the pepper severe mosaic virus coat protein gene. Plant Physiol. 103:1023.

32. Robaglia, C., Durand-Tardif, M., Tronchet, M., Boudazin, G., AstierManifacier, S., and Casse-Delbart, F. 1989. Nucleotide sequence of potato virus Y (N strain) genomic RNA. J. Gen. Virol. 70:935-947.

33. Singh, M., and Singh, R. P. 1996. Nucleotide sequence and genome organization of a Canadian isolate of the common strain of potato virus $\mathrm{Y}$ $\left(\mathrm{PVY}^{\mathrm{O}}\right)$. Can. J. Plant Pathol. 18:209-214.

34. Siriwong, P., Kittipakorn, K., and Ikegami, M. 1995. Characterization of chili vein-banding mottle virus isolated from pepper in Thailand. Plant Pathol. 44:718-727.

35. Spetz, C., Taboada, A. M., Darwich, S., Ramsell, J., Salazar, L. F., and Valkonen, J. P. T. 2003. Molecular resolution of a complex of potyviruses infecting solanaceous crops at the center of origin in Peru. J. Gen. Virol. $84: 2565-2578$

36. Spetz, C., and Valkonen, J. P. T. 2003. Genomic sequence of Wild potato mosaic virus as compared to the genomes of other potyviruses. Arch. Virol. 148:373-380.

37. Thompson, J. D., Higgins, D. G., and Gibson, T. J. 1994. CLUSTAL W: Improving the sensitivity of progressive multiple sequence alignment through sequence weighting, positions-specific gap penalties and weight matrix choice. Nucleic Acids Res. 22:4673-4680.

38. Vance, V. B., Moore, D., Turpen, T. H., Bracker, A., and Hollowell, V. C. 1992. The complete nucleotide sequence of pepper mottle virus genomic RNA: Comparison of the encoded polyprotein with those of other sequenced potyviruses. Virology 191:19-30.

39. van Regenmortel, M. H. V., Fauquet, C. M., Bishop, D. H. L., Carstens, E. B., Estes, M. K., Lemon, S. M., Maniloff, J., Mayo, M. A., McGeoch, D. J., Pringle, C. R., and Wickner, R. B., eds. 2000. Virus Taxonomy. Seventh report of the International Committee on Taxonomy of Viruses. Academic Press, San Diego, CA.

40. Walkey, D. G. A., Spence, N. J., Clay, M., and Miller, A. 1994. A potyvirus isolate from solanaceous hosts. Plant Pathol. 43:931-937.

41. Warren, C. E., and Murphy, J. F. 2003. The complete nucleotide sequence of Pepper mottle virus-Florida RNA. Arch. Virol. 148:189-197.

42. Yilmaz, M. A., Davis, R. F., and Varney, E. H. 1983. Viruses on vegetable crops along the Mediterranean coast of Turkey. (Abstr.) Phytopathology 73:378. 